\title{
Faktor-faktor kematangan implementasi e-government yang berorientasi kepada masyarakat
}

\author{
Anita Wulansari a Immah Inayati ${ }^{b}$ \\ a,b Program Studi Sistem Informasi, Universitas Narotama, Surabaya, Indonesia \\ email:anita.wsari@narotama.ac.id, bimmah.inayati@narotama.ac.id
}

\begin{tabular}{l}
\hline I N F O A R T I K E L \\
\hline Sejarah artikel: \\
Menerima 23 Agustus 2018 \\
Revisi 7 September 2018 \\
Diterima 7 September 2018 \\
Online 16 Mei 2019 \\
\hline
\end{tabular}

\section{Kata kunci:}

citizen-centric

e-government

grounded theory

penilaian kematangan

Surabaya Single Window

\begin{tabular}{l} 
Keywords: \\
citizen-centric \\
e-government \\
grounded theory \\
maturity measurement \\
Surabaya Single Window \\
\hline Style APA dalam mensitasi \\
artikel ini: \\
Wulansari, A., \& Inayati, I. \\
(2019). Faktor-faktor \\
kematangan implementasi \\
e-government yang \\
berorientasi kepada \\
masyarakat. Register: Jurnal \\
Ilmiah Teknologi Sistem \\
Informasi, 5(1), 24-36.
\end{tabular}

\begin{abstract}
ABSTRAK
Masyarakat merupakan pemegang kepentingan utama dalam penyelenggaraan e-government. Namun demikian, dalam konteks penelitian e-government, orientasi terhadap masyarakat masih belum banyak dieksploitasi karena sebagian besar proyek e-government hanya mentransformasi layanan dan informasi yang semula masih tradisional menjadi menggunakan teknologi. Model-model penilaian kematangan e-government yang sudah ada pun sebagian besar hanya mengukur kemampuan teknologi e-government. Oleh karena itu, perlu dikembangkan penilaian kematangan e-government yang menempatkan masyarakat sebagai fokus utamanya. Faktor-faktor kematangan didapatkan melalui pendekatan penelitian kualitatif grounded theory. Objek penelitian adalah layanan e-health dan Surabaya Single Window (SSW). Hasil penelitian menunjukkan ada tiga faktor yang diukur dalam penentuan kematangan e-government yang berorientasi kepada masyarakat, yaitu lembaga, interaksi, dan layanan online. Model ini diharapkan dapat digunakan sebagai alternatif alat penilaian implementasi e-government yang lebih komprehensif karena mengukur dari tiga sisi, yaitu lembaga pemerintah, interaksi pegawai pemerintah dengan masyarakat, dan layanan e-government yang disediakan.
\end{abstract}

\section{ABSTRACT}

Society is responsible for implementing e-government. Nevertheless, the context of research on e-government, orientation to society has not been exploited due to numerous projects which are only transformed service and information from previous traditional users to technology. Most of existing models of e-government was only used to determine the ability of the government. Therefore, it is necessary to develop maturity assessment of e-government placing society as major focus. Its factors are derivable from qualitative research approach of ground theory. The objects of research were e-health and Surabaya Single Window (SSW) services. The results of the study indicate that there were three factors measured in determining maturity of e-government oriented to society; the factors are institution, interaction and online services. This model could be used as more comprehensive alternative to assessment tool of e-government implementation because it measured three aspects, namely, institution, interaction of employees and provided egovernment services.

(c) 2019 Register: Jurnal IImiah Teknologi Sistem Informasi. Semua hak cipta dilindungi undang-undang.

\section{Pendahuluan}

Teknologi informasi dan komunikasi (TIK) telah mengubah proses, operasi, dan struktur sektor publik di negara maju maupun berkembang. Penerapan TIK dalam penyelenggaraan pemerintahan dianggap sebagai solusi hemat biaya yang dapat meningkatkan komunikasi antara instansi pemerintah dan konstituen mereka (Alshibly \& Chiong, 2015). Perubahan layanan publik dari sistem tradisional ke $e$ government memiliki banyak manfaat, antara lain penyampaian layanan yang berbiaya efektif, integrasi layanan, pengurangan biaya administratif, kesamaan cara pandang terhadap masyarakat di seluruh 
layanan pemerintah, serta mampu beradaptasi lebih cepat terkait kebutuhan masyarakat (Tavana, Zandi, \& Katehakis, 2013). Kemampuan e-government dapat bervariasi, mulai dari sekadar menyediakan informasi melalui situs jejaring, melakukan transaksi finansial, hingga berpartisipasi dalam e-democracy, misalnya melakukan pemungutan suara secara elektronik tentang kebijakan pemerintah melalui internet (Shahkooh, Saghafi, \& Abdollahi, 2008).

Selain lembaga pemerintahan, pemegang kepentingan di dalam pemerintahan digital adalah masyarakat dan bisnis (Robertson \& Vatrapu, 2010). Pelibatan masyarakat, tidak hanya sebagai pengguna layanan, tetapi juga dalam menentukan layanan yang akan disediakan telah menjadi isu penting dalam tata kelola teknologi informasi (Eijk \& Steen, 2014). Meski demikian, dalam konteks penelitian e-government, baik praktisi maupun ilmuwan akademik berpendapat bahwa orientasi terhadap masyarakat masih belum banyak dieksploitasi (Greitens \& Strachan, 2011). Sebagian besar proyek e-government hanya mentransformasi layanan dan informasi yang semula masih tradisional menjadi pengguna teknologi tanpa melibatkan perubahan institusional dan organisasional (Nations, 2003). Kajian terhadap berbagai model kematangan menunjukkan bahwa: (1) meskipun nama tahapan untuk tiap model kematangan berbeda, tetapi secara isi dimungkinkan adanya kemiripan; (2) fitur utama pada setiap model kematangan adalah tersedianya layanan satu pintu, transaksi dan partisipasi elektronik, serta integrasi antarlembaga (Fath-Allah, Cheikhi, Al-Qutaish, \& Idri, 2014).

Hasil penelitian Debrí \& Bannister (2015) juga menunjukkan bahwa, model-model penilaian kematangan e-government yang sudah ada pun sebagian besar adalah model asimilasi teknologi yang melaporkan kemampuan lembaga pemerintah untuk mengadopsi dan menggunakan teknologi. Selain itu, seluruh model e-government diawali dengan perkembangan layanan jejaring dan internet serta secara luas mendefinisikan e-government sebagai penyampaian informasi berbasis jejaring. Sebagian besar model penilaian kematangan e-government hanya melihat kematangan implementasi e-government dari faktor teknologi atau infrastruktur, misalnya situs, portal, aplikasi, dan jaringan. Meskipun ada yang menilai dari faktor nonteknologi, tetapi model tersebut hanya menilai kesiapan e-government dan bukan kematangannya (Napitupulu \& Sensuse, 2014). Oleh karena itulah diperlukan sebuah model untuk menilai kematangan implementasi e-government yang berorientasi kepada masyarakat.

\section{State of the Art}

\subsection{Faktor-faktor yang mempengaruhi manajemen hubungan masyarakat di dalam pemerintahan}

Sebuah penelitian kualitatif berdasarkan studi kasus dilakukan untuk mendapatkan faktor-faktor yang menentukan keberhasilan implementasi CiRM (Citizen Relationship Management). Pemilihan studi kasus didasarkan pada kajian yang lengkap terkait implementasi CiRM dan tulisan-tulisan yang meneliti adanya keterlibatan langsung di dalam proses implementasi. Terdapat empat studi kasus yang dikaji yaitu implementasi CiRM di Miami, Iran, Boston, dan Dubai. Di dalam model yang diajukan, didefinisikan sepuluh aspek yang menentukan implementasi inisiatif CiRM, yaitu (Andrade \& Camacho, 2014):

1. CiRM oriented management: adanya perubahan pola pikir pemerintah, pegawai, dan pejabatnya yang menjadikan kepuasan masyarakat sebagai tujuan utama dan tidak hanya sekadar menjalankan tugas;

2. Leadership, vision, and commitment: adanya seseorang atau sekelompok orang yang memiliki visi kuat untuk mengimplementasikan perubahan tersebut (system champion dan management support);

3. Support function: adanya dukungan TIK yang baik;

4. Centralization of IS: adanya sistem informasi terpusat yang menyediakan berbagai layanan yang dibutuhkan oleh masyarakat dan dapat diakses juga oleh seluruh pegawai instansi pemerintahan, terutama untuk hal-hal tertentu, misalnya bencana nasional dan pergolakan politik;

5. Coordination and cooperation: adanya integrasi berbagai sistem yang dimiliki pemerintah;

6. Management: kemampuan untuk dapat mengelola impelementasi CiRM yang meliputi tiga hal, yaitu perencanaan strategis, pembentukan tim manajemen proyek, dan peningkatan kemampuan TI; 
7. Citizen: menggambarkan hubungan antara masyarakat dengan pemerintah. Keberhasilan implementasi CiRM ditentukan oleh partisipasi masyarakat, keterlibatan pemerintah terhadap masyarakat, dan penerimaan masyarakat terhadap teknologi baru;

8. Channels: menggambarkan kemampuan CiRM untuk mendapatkan informasi terbaru dalam jangka panjang. Aspek ini meliputi communication channel, CiRM tool extensions, information access, dan innovation;

9. Integration: integrasi antara sistem CiRM dengan data kota;

10. Legal: adanya kebijakan dan peraturan terkait implementasi CiRM.

\subsection{Kerangka kerja COBRA (constructs: cost; benefit; risk and opportunity) untuk menilai layanan e- government dari perspektif pelanggan}

Metodologi pengembangan model yang digunakan adalah pendekatan grounded theory. Tinjauan secara luas terhadap literatur mengenai model penilaian layanan elektronik dilakukan untuk mengidentifikasi berbagai faktor keberhasilan implementasi layanan elektronik (KPI). KPI yang teridentifikasi kemudian diklasifikasikan ke dalam empat kelompok utama yaitu biaya, manfaat, risiko, dan kesempatan. Dengan demikian, kepuasan pengguna diukur melalui analisis biaya-manfaat dan risiko-peluang ketika berinteraksi dengan e-service. Tujuan dari Osman, dkk (2014) adalah mengembangkan model yang komprehensif untuk mengevaluasi kepuasan pengguna terhadap layanan e-government, mengembangkan dan melakukan validasi skala yang digunakan untuk menilai kepuasan pengguna dan melakukan validasi hubungan antarvariabel dalam model yang diusulkan.

Dalam model Osman, dkk (2014), variabel independennya adalah biaya, manfaat, risiko dan kesempatan. Sementara, variabel dependennya adalah kepuasan pengguna. Pada awalnya, terdapat 60 item yang disertai dengan pertanyaan terbuka pada kuesioner yang diberikan kepada 20 ahli yang merupakan pegawai pemerintah, spesialis teknologi informasi (TI), serta peneliti profesional di bidang e-government. Hasilnya, 60 item tersebut diperbarui dan dikoreski menjadi 49 item. Selanjutnya, dilakukan face validity untuk mengevaluasi kuesioner tersebut oleh 30 mahasiswa Master of Business Administration (MBA). Kemudian, dilakukan survei online yang mampu mendapatkan 2.785 data. Setelah itu, dilakukan explanatory factor analysis dan confirmatory factor analysis pada data tersebut. Hasilnya adalah manfaat dan kesempatan memiliki relasi yang positif dengan kepuasan pengguna, sedangkan biaya dan risiko memiliki relasi yang negatif dengan kepuasan pengguna. Kelebihan model ini adalah melengkapi model Value Measurement Model (VMM) dengan menambahkan satu variabel yaitu kesempatan dan lebih komprehensif bila dibandingkan dengan Service Quality (SERVQUAL). Salah satu kekurangan model ini adalah belum dipertimbangkannya faktor lain yang dapat berpengaruh terhadap kepuasan pengguna, misalnya budaya atau strategi pengembangan layanan $e$ government.

\subsection{Pengaruh pemberdayaan pelanggan dalam keberhasilan e-government}

Penelitian yang dilakukan Alshibly dan Chiong (2015) bertujuan untuk mengetahui dampak pemberdayaan pelanggan terhadap keberhasilan e-government. Terdapat empat variabel yang diukur dalam penelitian Alshibly dan Chiong (2015), yaitu personalisasi, kepercayaan, pemberdayaan pelanggan dan keberhasilan e-government. Hipotesis yang diajukan adalah pemberdayaan pelanggan berpengaruh positif terhadap keberhasilan e-government, personalisasi berpengaruh positif terhadap pemberdayan pelanggan, kepercayaan berpengaruh positif terhadap pemberdayaan pelanggan dan personalisasi berpengaruh positif terhadap kepercayaan.

Sebelum kuesioner dibagikan, dilakukan face validity oleh 14 mahasiswa pascasarjana. Data diperoleh dari kuesioner yang diisi oleh 176 responden. Setiap responden diminta memberikan nilai untuk tiap item pada kuesioner menggunakan skala Likert. Setelah itu data diolah menggunakan metode Partial Least Squares-Structural Equation Modeling (PLS-SEM). Hasilnya adalah semua hipotesis yang diajukan terbukti, sehingga keberhasilan implementasi e-government juga bergantung pada pemberdayaan masyarakat oleh pemerintah. Kekurangan penelitian Alshibly dan Chiong (2015) adalah penelitian dilakukan secara cross-sectional, item pertanyaan pada kuesioner lebih fokus pada desain, komunikasi pada layanan e-government dibandingkan konten dan dan hasil.

\subsection{Pelayanan publik yang melibatkan masyarakat dan pegawai pemerintah}


Menurut Giesbrecht, Scholl, dan Schwabe (2016), implementasi e-government berhasil membantu masyarakat memperoleh informasi yang sederhana dan melakukan proses transaksi standar. Meski demikian, mereka masih sulit mendapatkan kebutuhan atau informasi yang lebih kompleks. Ketika keadaan berubah, mereka membutuhkan saran yang sifatnya personal di bagian depan pelayanan lembaga pemerintah. Hal ini mengakibatkan perlunya organisasi menerapkan konsep one stop government yang memberikan pelayanan terintegrasi kepada masyarakat. Namun kenyataannya, pegawai pemerintah lebih berfungsi sebagai administrator yang hanya mempunyai wewenang untuk memproses transaksi standar. Terlebih lagi, secara fisik, pegawai dan masyarakat diposisikan sebagai dua pihak yang berlawanan yang dipisahkan dengan meja panjang. Hal ini menunjukkan bahwa kantor pemerintah didesain untuk memproses permintaan dengan cepat daripada memfasilitasi kolaborasi antara dua pihak yang setara posisinya.

Tujuan penelitian Giesbrecht, Scholl, dan Schwabe (2016) adalah untuk menemukan cara agar pegawai pemerintah di bagian pelayanan mampu diberdayakan untuk menyediakan layanan yang berorientasi kepada masyarakat. Metodologi penelitian Giesbrecht, Scholl, dan Schwabe (2016) terdiri atas empat tahapan, yaitu (1) formulasi masalah, (2) pembuatan, intervensi, dan evaluasi; (3) refleksi dan pembelajaran, dan (4) formalisasi pembelajaran. Hasil kolaborasi peneliti Giesbrecht, Scholl, dan Schwabe (2016) dengan pemerintah salah satu daerah di Jerman ini menghasilkan konsep advisory information artifact yang menyediakan dukungan yang komprehensif bagi pegawai publik di bagian pelayanan kantor pemerintahan dan memberdayakan mereka untuk menyediakan layanan yang berorientasi kepada masyarakat. Advisory information artifact terdiri atas tiga hal, yaitu pusat pengetahuan terintegrasi, konselor konseling dan service encounter thinkLets. Pusat pengetahuan terintegrasi adalah terintegrasinya seluruh layanan beserta informasi yang berkaitan dengan tiap-tiap layanan. Konselor konseling ditunjukkan dengan karakteristik teknis yang mendorong pegawai pemerintah untuk menunjukkan perilaku mau memberikan saran. Service encounter thinkLets menyediakan pedoman perilaku sosial yang berisi informasi tentang praktik terbaik untuk kegiatan pemecahan masalah kolaboratif dalam pertemuan layanan konsultasi dengan masyarakat.

\subsection{Kajian berbagai model kematangan e-government}

Sebanyak 25 model kematangan e-government telah dikaji dan dibandingkan oleh Fath-Allah, Cheikhi, Al-Qutaish, dan Idri (2014) untuk menemukan persamaan dan perbedaan serta kelebihan dan kekurangan di antara model-model tersebut. Seluruh model yang dikaji termasuk ke dalam kelompok 3 yaitu the evolutionary e-government maturity models. Dari kajian tersebut didapatkan empat topik utama seputar model-model kematangan e-government, yaitu (1) nama tiap tahapan kematangan, (2) jumlah tahapan, tahun, dan negara yang menggunakan suatu model kematangan, (3) fokus tiap tahapan kematangan, dan (4) fitur tahapan kematangan. Secara detail dijelaskan sebagai berikut (Fath-Allah, Cheikhi, Al-Qutaish, \& Idri, 2014):

1. Nama tahapan kematangan

Meskipun nama tahapan untuk tiap model kematangan berbeda, tetapi secara isi dimungkinkan adanya kemiripan atau perbedaan. Sebagai contoh, tahap pertama pada model Layne dan Lee disebut "catalogue". Model catalogue yaitu kewenangan publik disajikan melalui situs jejaring, sementara pada model yang dibuat oleh Perserikatan Bangsa-Bangsa (PBB), tahapan ini dinamakan "emerging information services". Tahapan emerging information services yaitu situs pemerintah menyediakan informasi yang sifatnya statis. Sementara, pada model Lee dan Kwak, tahapan ini disebut "initial conditions". Tahapan initial conditions yaitu penyebarluasan informasi kepada masyarakat. Apalagi, hampir seluruh model tersebut mengandung (a) tahapan yang terkait dengan ketersediaan informasi pada situs jejaring (presence), (b) tahapan masyarakat dapat berinteraksi dengan pemerintah (interact), (c) tahapan masyarakat dapat bertransaksi dengan pemerintah (transact), dan (d) tahap lanjut yang mencakup fitur-fitur canggih seperti berbagi pakai informasi antarlembaga (integration).

2. Jumlah tahapan, tahun dan negara yang menggunakan suatu model kematangan

Jumlah tahapan kematangan yang berbeda pada ke- 25 model kematangan $e$-government yang diuji dengan jumlah tahapan paling sedikit adalah dua dan paling banyak adalah enam. Seluruh model yang dikaji dikembangkan antara tahun 2001 hingga 2012 dengan jumlah satu hingga dua model 
tiap tahunnya. Tidak semua model digunakan atau dijadikan acuan untuk menilai kematangan implementasi e-government. Hanya empat belas model yang pernah digunakan oleh suatu negara, terutama model kematangan e-government yang dikembangkan oleh PBB yang digunakan oleh seluruh anggotanya.

3. Fokus tiap tahapan kematangan

Seluruh model, kecuali Andersen dan Wescott sepakat bahwa pada tahap awal e-government yang terjadi adalah munculnya situs milik pemerintah. Tahap selanjutnya adalah dapat dilakukannya proses interaksi, transaksi, personalisasi dan integrasi. Tahapan paling tinggi yang dicapai oleh sebuah implementasi e-government adalah ketika masyarakat dapat berpartisipasi di dalam proses penyelenggaraan pemerintahan.

4. Fitur tahapan kematangan

Terdapat enam fitur utama yang tercakup di dalam seluruh model kematangan yang dikaji, yaitu:

- One stop shops: situs e-portal merupakan pintu tunggal untuk mengakses seluruh layanan $e$ government;

- Customer centricity: layanan e-portal didesain dari perspektif masyarakat dan bukan organisasi;

- Interoperability: adanya kerja sama antarlembaga pemerintah dan pertukaran informasi;

- Personalization: dimungkinkannya masyarakat untuk melakukan personalisasi dan kustomisasi berbagai fungsionalitas e-portal sesuai kebutuhannya;

- Payment: masyarakat dapat melakukan pembayaran di dalam e-portal melalui kartu debit atau kredit atau electronic banking;

- E-participation: terlibatnya masyarakat di dalam berbagai proses e-government menggunakan berbagai perangkat, seperti lembar pendapat, survei, e-voting dan e-petitioning.

\section{Metode Penelitian}

Penelitian ini menggunakan pendekatan kualitatif grounded theory. Pendekatan ini dipilih karena grounded theory merupakan rancangan penelitian kualitatif yang hasilnya memunculkan teori tentang proses, aksi, atau interaksi yang disarikan dari pendapat beberapa partisipan. Grounded theory disediakan untuk memunculkan teori (lengkap dengan diagram dan hipotesis) tentang ketiga hal tersebut dengan saling menghubungkan kategori informasi berdasarkan pada data yang dikumpulkan dari individu (Creswell, 2015).

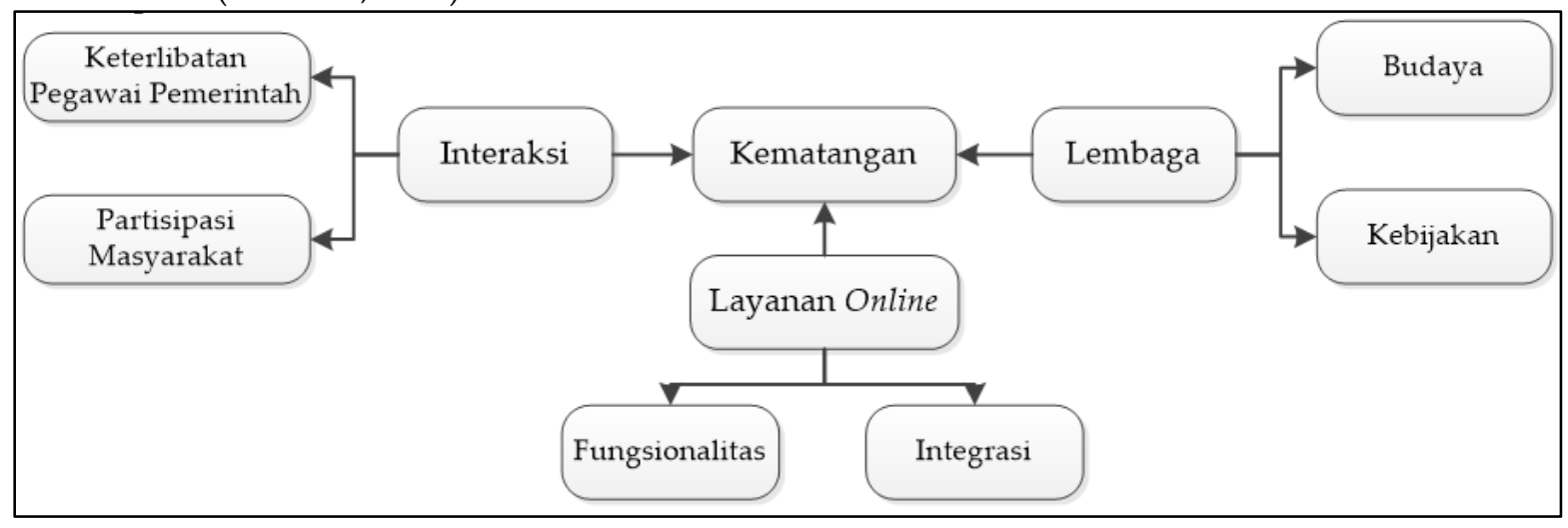

Gambar 1. Model konseptual penelitian

\subsection{Penyusunan model konseptual}

Dalam penelitian ini, faktor-faktor kematangan yang diikutsertakan ke dalam model konseptual penelitian merupakan sisntesis dari seluruh faktor yang telah dipaparkan pada penelitian-penelitian sebelumnya. Selanjutnya dilakukan analisis domain untuk mencari hubungan antarelemen dengan domainnya. Model konseptual yang berisi domain penelitian beserta elemen-elemen dalam tiap domain dapat dilihat pada Gambar 1. Lembaga meliputi budaya (citizen-centric management), dan kebijakan. Interaksi terdiri atas partisipasi masyarakat dan keterlibatan pegawai pemerintah. Layanan meliputi fungsionalitas layanan (publishing, interaction, transaction, dan participation) dan integrasi teknologi secara vertikal dan horizontal.

Selanjutnya adalah penentuan proposisi yang merupakan rancangan usulan, ungkapan yang dapat diyakini, diragukan, dibantah, atau dibuktikan benar tidaknya. Dalam penelitin ini terdapat dua 
proposisi, yaitu proposisi minor dan proposisi mayor. Proposisi minor merupakan pernyataan bermakna dari setiap kategori utama yang digunakan pada penelitian berdasarkan informasi yang ada. Proposisi minor pada penelitian ini adalah (1) budaya (citizen-centric) merupakan faktor yang diukur dalam penentuan kematangan e-government yang berorientasi kepada masyarakat, (2) kebijakan merupakan faktor yang diukur dalam penentuan kematangan e-government yang berorientasi kepada masyarakat, (3) keterlibatan pegawai pemerintah merupakan faktor yang diukur dalam penentuan kematangan e-government yang berorientasi kepada masyarakat, (4) partisipasi masyarakat merupakan faktor yang diukur dalam penentuan kematangan e-government yang berorientasi kepada masyarakat, (5) fungsionalitas sistem merupakan faktor yang diukur dalam penentuan kematangan e-government yang berorientasi kepada masyarakat, dan (6) integrasi layanan merupakan faktor yang diukur dalam penentuan kematangan e-government yang berorientasi kepada masyarakat. Sementara, proposisi mayor adalah pernyataan simpulan secara umum berdasarkan simpulan yang diperoleh pada proposisi minor. Proposisi mayor pada penelitian ini adalah kematangan e-government yang berorientasi kepada masyarakat dapat diukur menggunakan tiga dimensi yaitu lembaga, interaksi, dan layanan.

\subsection{Validasi model konseptual}

Tujuan validasi model konseptual adalah untuk memastikan model konseptual yang dibangun oleh peneliti sesuai dengan model yang diinginkan masyarakat, yang diwakili oleh informan, ketika mereka ingin menilai implementasi e-government. Validasi model dilakukan dengan membandingkan model konseptual yang dibangun oleh peneliti dengan hasil analisis data yang didapat melalui pendekatan penelitian kualitatif berbasis grounded theory. Dari langkah tersebut dapat diketahui persamaan dan perbedaan di antara keduanya sekaligus merepresentasikan perbedaan antara proposisi yang disusun pada awal penelitian dengan hasil analisis data. Selanjutnya, dilakukan perbaikan terhadap model agar model dapat mencakup penilaian e-government yang diinginkan masyarakat.

Validasi model dilakukan dengan mewawancarai warga dan pebisnis yang memiliki pengalaman dalam menggunakan layanan e-government selama lebih dari satu tahun. Objek dalam penelitian ini adalah aplikasi e-government pemerintah Surabaya yang dimiliki, yaitu $e$-Health dan SSW (Surabaya Single Window). Dua puluh empat responden diminta untuk menjawab sembilan belas pertanyaan terbuka untuk menentukan faktor-faktor e-government yang berorientasi kepada masyarakat. Kemudian, dilakukan validitas dan reliabilitas data wawancara dengan menggunakan triangulasi dan proses member checking. Triangulasi adalah metode yang digunakan oleh peneliti untuk memeriksa dan menetapkan validitas dalam penelitian mereka dengan menganalisis pertanyaan penelitian dari berbagai perspektif untuk memastikan konsistensi pada seluruh sumber data. Ada dua jenis triangulasi yang digunakan dalam penelitian ini yaitu triangulasi sumber data dan triangulasi waktu. Triangulasi sumber data dilakukan dengan melakukan wawancara kepada informan yang berbeda tetapi berpengalaman menggunakan aplikasi yang sama. Sementara, triangulasi waktu dilakukan dengan melakukan wawancara kepada informan yang sama berulang kali. Proses member checking, yang juga dikenal sebagai umpan balik informan atau validasi responden, dilakukan setelah proses wawancara. Para informan diminta untuk memastikan akurasi informasi yang dikumpulkan dalam penelitian ini.

\subsection{Analisis data}

Setelah model dinyatakan valid, maka selanjutnya dilakukan proses analisis data. Tahap pertama dari proses analisis data, menurut manajemen data analisis spiral, adalah pengorganisasian data. Proses pengorganisasian data dilakukan dengan mengelompokkan informasi dari rekaman wawancara menjadi beberapa bagian. Setelah mengatur data, tahap selanjutnya adalah analisis data untuk menginterpretasikan basis data secara keseluruhan yang berarti mencoba menafsirkan wawancara secara keseluruhan. Selanjutnya ditulislah hasil wawancara ke dalam dokumen (memoing) untuk memfasilitasi proses mendeskripsikan, mengklasifikasikan dan menafsirkan data pada naskah wawancara.

\section{Hasil dan Pembahasan}

Pada tahap pengodean terbuka, ditemukan kategori yang menjadi fokus penelitian ini, yaitu faktor kematangan e-government yang berorientasi pada masyarakat. Kemudian, pada tahap pengodean aksial, 
basis data wawancara dieksploitasi untuk mengonfirmasi indikator apa saja yang diukur. Pada tahap akhir yaitu pengodean selektif, ditemukan faktor baru pada domain layanan yaitu kemudahan penggunaan dan keandalan layanan (reliability) Model terakhir dari penelitian ini ditunjukkan pada Gambar 2.

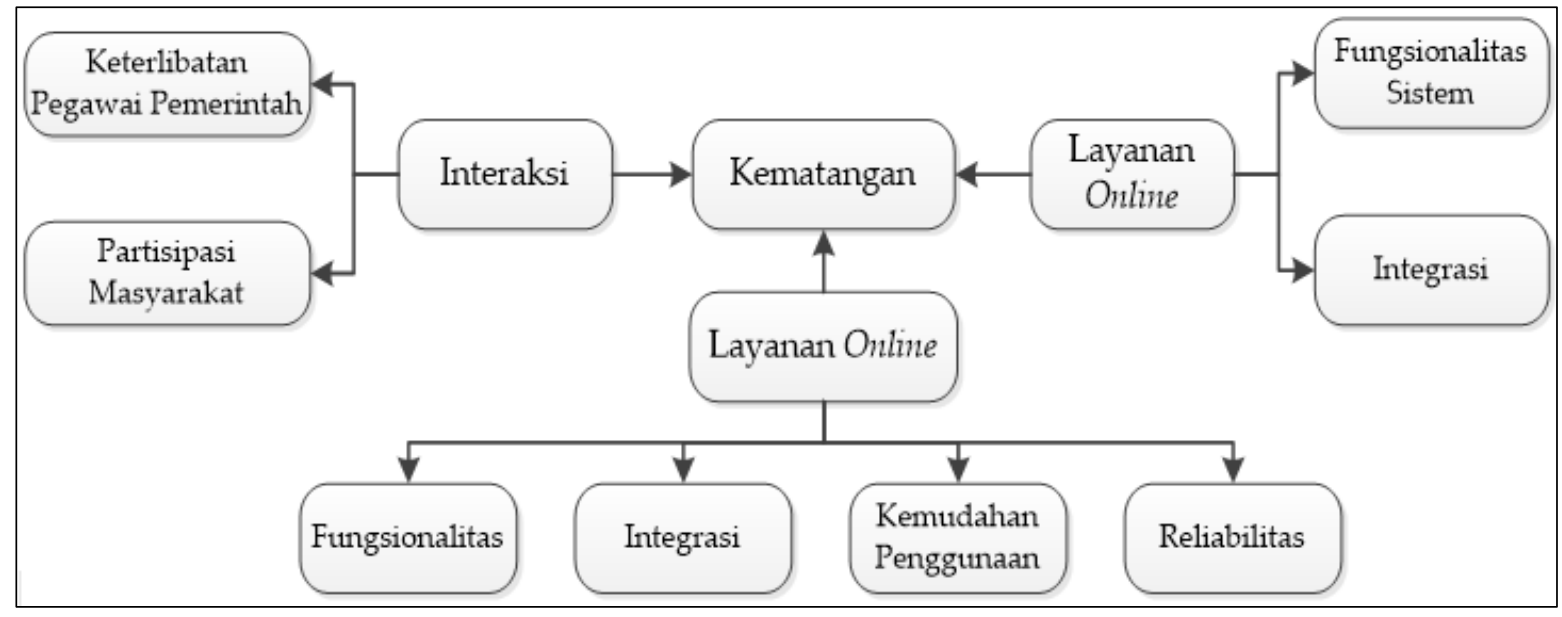

Gambar 2. Model akhir

\subsection{Budaya lembaga}

Orientasi terhadap pelanggan, dalam hal ini adalah masyarakat, merujuk pada penempatan masyarakat sebagai pusat dari seluruh aktivitas organisasi untuk membangun hubungan jangka panjang secara bertahap. Oleh karena itulah, variabel ini merupakan komponen fundamental yang dibutuhkan bagi organisasi untuk mencapai kesuksesan dalam CiRM. Tabel 1 menunjukkan pernyataan hasil wawancara terhadap informan:

Tabel 1. Transkrip wawancara 1

\begin{tabular}{|c|c|}
\hline Informan & Pernyataan \\
\hline Informan 1 & $\begin{array}{l}\text { Ya, perlu sekali. Kalo saya pribadi intinya yang bisa mempermudah, mempercepat, trus kalo } \\
\text { misalkan ada masalah bisa di-solving. }\end{array}$ \\
\hline Informan 3 & Perlu sih menurutku. Biar SDM kita semakin maju gitu, ga perlu pake hardcopy lagi. \\
\hline Informan 7 & $\begin{array}{l}\text { Sangat perlu, pelayanan yang mengedepankan kepuasan masyarakat, tidak seperti saat ini } \\
\text { "Senang melihat orang lain susah, susah melihat orang lain senang". }\end{array}$ \\
\hline Informan 13 & $\begin{array}{l}\text { Sangat perlu ya mbak. Karena kalo semisal tidak ada perubahan paradigma tentunya aplikasi } \\
\text { online itu hanya sebagai alternatif atau penghibur saja. }\end{array}$ \\
\hline
\end{tabular}

Kata-kata kunci seperti: "sangat perlu", "perlu sekali", "perubahan paradigma", "harus orientasi ke masyarakat", menunjukkan bahwa perubahan mindset (cara berpikir) pemerintah memiliki peran penting dalam keberhasilan implementasi e-government yang berorientasi pada masyarakat. Semua bentuk aktivitas yang bersentuhan dengan publik harus dilakukan dengan rasa ingin memberikan pelayanan dan bukan sekadar menjalankan tugas. Hal ini sesuai dengan penelitian sebelumnya, yaitu Garrido-Moreno, Lockett, dan García-Morales (2014) dan Andrade \& Camacho (2014), bahwa pemerintah yang benar-benar berorientasi kepada masyarakat akan dapat mendesain proses bisnisnya dengan lebih baik karena diperlukan budaya organisasi yang kondusif untuk meningkatkan pemahaman pegawai mengenai masyarakat. Kepuasan masyarakat adalah tujuan organisasi ketika memberikan pelayanan. Selain itu, pemberian nilai tambah bagi masyarakat harus menjadi dasar pembuatan kebijakan organisasi (Andrade \& Camacho, 2014).

\subsection{Kebijakan}

Faktor-faktor organisasional pada sektor publik berkaitan erat dengan peraturan, regulasi, hukum atau kebijakan. Peraturan dan kebijakan dapat memastikan perilaku organisasi dan mengarahkan pada efisiensi dan efektifitas (Lawson-Body, Willoughby, Mukankusi, \& Logossah, 2011). Kebijakan menyangkut peraturan baik tertulis maupun lisan, formal maupun informal terkait dengan implementasi layanan online. Tabel 2 menunjukkan pernyataan dari wawancara terhadap informan.

Kata-kata kunci seperti "nge-drive bawahan", "membuat perwalinya", "mewajibkan bawahannya", "komitmen untuk selalu menggunakan", "kebijakan lisan maupun tertulis", 
"menginisiasi dan memotivasi", "peraturan", "regulasi-regulasi", "dukungan untuk melakukan perbaikan", "perda", "kontrol di lapangan", "evaluasi" dan "ada reward dan punishment" menunjukkan bahwa ketika pimpinan lembaga pemerintahan mendukung pelaksanaan layanan online. Hal tersebut harus ditunjukkan dengan membuat kebijakan yang dapat memotivasi, mengawasi, dan mengevaluasi jalannya implementasi layanan online. Hasil wawancara menunjukkan bahwa penting adanya kebijakan, baik secara tertulis maupun lisan, yang mengatur tentang implementasi citizen-centric egovernment, karena hanya peraturanlah yang dapat mengikat dan memaksa seluruh pemegang kepentingan di dalam layanan publik untuk terlibat aktif dalam menyukseskan implementasi citizencentric e-government. Hal ini sesuai dengan yang dikemukan oleh (Andrade \& Camacho, 2014). Kebijakan yang memihak masyarakat dinilai dari peraturan atau instruksi tentang penggunaan layanan online yang ditetapkan dan sosialisasi yang dilakukan pemerintah terkait layanan online melalui berbagai media.

Tabel 2. Transkrip wawancara 2

\begin{tabular}{|c|c|}
\hline Informan & Pernyataan \\
\hline Informan 9 & $\begin{array}{l}\text { Pejabat pemerintah itu justru harus menginisiasi dan memotivasi pegawai pemkotnya. } \\
\text { Dukungan yang kalo tingkat tinggi itu biasanya kalo ada peraturan atau mungkin regulasi- } \\
\text { regulasi yang bisa meringankan atau mendukung masyarakat. Ada beberapa mungkin ya, } \\
\text { seperti mengeluarkan beberapa peraturan pemda, entah itu regulasi atau dukungan untuk } \\
\text { melakukan perbaikan sana-sini. }\end{array}$ \\
\hline Informan 15 & $\begin{array}{l}\text { Kalo dalam hal Surabaya, kan dari walikota harus ada perda yang mengatur tentang penerapan } \\
\text { aplikasi online di Surabaya khususnya buat warga. Terus yang kedua itu, kontrol di lapangan. } \\
\text { Yang ketiga evaluasi. Jadi targetan-targetan pemerintah itu apa. Perlu kebijakan dari segi } \\
\text { peraturan dan SOP. Selain kebijakan berupa perda atau perwali perlu ada reward dan } \\
\text { punishment. }\end{array}$ \\
\hline
\end{tabular}

\subsection{Keterlibatan pegawai pemerintah}

Tabel 3. Transkrip wawancara 3

\begin{tabular}{|c|c|}
\hline Informan & Pernyataan \\
\hline Informan 2 & $\begin{array}{l}\text { Harus terlibat juga. Pegawai yang mau terlibat sedikit, karena lebih milih pake hardcopy } \\
\text { (pegawainya,red.). Jadi ga mau buka laptop terus nyari datanya. }\end{array}$ \\
\hline Informan 6 & Keterlibatan petugas sangat penting, menjaga agar implementasi tersebut terus berjalan. \\
\hline Informan 11 & $\begin{array}{l}\text { Perlu banget, karena aplikasi online ini kan mereka (pegawai pemerintah) sendiri yang } \\
\text { menjalankan. Mereka termasuk bagian dari rantai sistemnya. Yang pasti sih baik aparat, } \\
\text { pejabatnya ataupun pegawainya itu bisa melayani apa yang dibutuhkan masyarakat. Jadi } \\
\text { misalkan untuk ngurus surat tertentu ga cuman minta persyaratannya tapi juga membantu } \\
\text { memberikan informasinya, membantu bagaimana mengarahkan yang baik untuk menyiapkan } \\
\text { dokumen-dokumennya atau persyaratan lain yang didukung. }\end{array}$ \\
\hline Informan 17 & $\begin{array}{l}\text { Nah harapannya partisipasi pemerintah selaku penyelenggara layanan publik khusunya yang } \\
\text { berbasis online ini mampu terlibat aktif dan persuasif. Persuasif yang seperti apa? Pertama } \\
\text { mengenalkan, mengedukasi tentang minimal adanya layanan online itu. Yang kedua aktif dalam } \\
\text { berpartisipasi membantu warga untuk yang gak bisa menggunakan layan online itu, dibantu di- } \\
\text { guidance, seperti itu. }\end{array}$ \\
\hline
\end{tabular}

Kesuksesan pelayanan bergantung pada infrastruktur teknologi informasi dan pegawai yang memahami layanan yang diberikan secara komprehensif. Pegawai pemerintah dan kontribusi mereka merupakan faktor penting bagi keberlangsungan pelayanan yang berorientasi kepada masyarakat (Andrade \& Camacho, 2014).

Tabel 3 menunjukkan pernyataan dari wawancara terhadap informan. Kata-kata kunci seperti "keterlibatan petugas sangat penting", "mereka (pegawai pemerintah) sendiri yang menjalankan", dan "bagian dari rantai sistemnya" menunjukkan bahwa tidak hanya pimpinan pemerintahan yang harus peduli terhadap implementasi layanan online, tetapi keterlibatan seluruh pegawai pemerintah, terutama yang langsung bersentuhan dengan publik, menjadi faktor utama keberhasilan implementasi layanan online. Sementara, kata-kata kunci seperti "mengenalkan", "mengedukasi", "membantu warga", "dibantu di-guidance", "pelayanan komunikasi" dan "melayani apa yang dibutuhkan masyarakat" menunjukkan bentuk partisipasi pegawai pemerintah yaitu sebagai pihak yang aktif dalam 
memberikan informasi dan mengedukasi masyarakat terkait adanya layanan online dan membantu mereka hingga dapat menggunakan layanan online tersebut, sekaligus sebagai pengguna layanan online.

Pegawai pemerintah, khususnya yang langsung berhadapan dengan masyarakat, merupakan pihak yang terlibat langsung di dalam penyelenggaraan pelayanan publik. Baik tidaknya penyelenggaraan pelayanan publik oleh pemerintah dapat dilihat dari kualitas pelayanan yang diberikan oleh pegawai pemerintah. Pegawai yang memiliki komitmen akan mampu mengatasi hambatan-hambatan fungsional sekaligus membaktikan dirinya untuk melakukan aktivitas-aktivitas yang berorientasi kepada masyarakat (Garrido-Moreno, Lockett, \& García-Morales, 2014). Keterlibatan pegawai pemerintah yang diharapkan oleh masyarakat adalah bahwa mereka tidak hanya sebagai pengguna, tetapi juga mengenalkan layanan online, memandu masyarakat dalam penggunaan layanan online, hingga mampu memberikan informasi yang dibutuhan masyarakat dengan cepat, tepat, dan sikap yang baik.

\subsection{Partisipasi masyarakat}

E-government bertujuan untuk mengembangkan dialog antara pemerintah dengan masyarakat. Jika pemerintah mampu menemukan cara untuk berkomunikasi dengan masyarakatnya, bukan menjadi jaminan masyarakat akan merespons hal tersebut. Pemerintah perlu meningkatkan kesadaran bahwa kebutuhan masyarakat adalah prioritas pertama dan pemerintah akan melakukan apa saja untuk memenuhi hal tersebut (Andrade \& Camacho, 2014). Apalagi, masyarakat merupakan pemegang kepentingan utama bagi penyelenggaraan layanan publik. Terlebih lagi, keberhasilan e-government turut ditentukan oleh tingkat partisipasi masyarakat (Alshibly \& Chiong, 2015). Mereka adalah objek sekaligus subjek layanan itu sendiri. Tabel 4 menunjukkan pernyataan dari wawancara terhadap informan.

Tabel 4. Transkrip wawancara 4

\begin{tabular}{|c|c|}
\hline Informan & Pernyataan \\
\hline Informan 4 & $\begin{array}{l}\text { Berpartisipasi itu penting, karena user-nya tetep masyarakat. Jadi bagaimana masyarakat bisa } \\
\text { menjangkau aplikasi online, itu yang penting. Partisipasi masyarakat itu bisa membantu } \\
\text { pemerintah kota untuk menyusun kebijakan atau perencanaan ke depannya. }\end{array}$ \\
\hline Informan 10 & $\begin{array}{l}\text { Kalo terlibat sih, pasti ya mbak, karena sebagai bagian dari kebutuhan kita juga sih sebagai } \\
\text { warga Surabaya. Masyarakat pun harus tahu. Penggunaan oleh masyarakat itu juga sebagai } \\
\text { penilaian. Jadi ketika kita sudah melakukan pendaftaran via online, otomatis kita juga akan } \\
\text { menginformasikan ke rekan-rekan yang lain gitu lho. Sebagai pengguna dulu terus } \\
\text { mensosialisasikan, "eh ini mudah lho sekarang". }\end{array}$ \\
\hline Informan 14 & $\begin{array}{l}\text { Jadi warga juga tetep perlu dilibatkan dalam partisipasi ya. Partisipasi masyarakat di sini, } \\
\text { penerimaan masyarakat terkait pelayanan publik tersebut. Yang pertama itu, ada rasa ingin tahu } \\
\text { atau inisiatif untuk mengenal layanan online apa saja yang sudah ada di pemkot. Minimal tahu } \\
\text { kan? seperti itu dan ingin belajar. Yang kedua, partisipasi untuk menggunakan. }\end{array}$ \\
\hline
\end{tabular}

Kata-kata kunci seperti "Berpartisipasi itu penting", "Kalo terlibat sih, pasti ya", dan "perlu dilibatkan dalam partisipasi" menunjukkan bahwa salah satu hal yang menentukan keberhasilan implementasi layanan online adalah keterlibatan masyarakat di dalamnya. Partisipasi masyarakat tersebut dapat diwujudkan dalam bentuk yang beragam, misalnya berinisiatif untuk mencari tahu layanan online apa saja yang disediakan oleh pemerintah, ikut menyosialisasikan keberadaan layanan online yang tersedia, aktif menggunakan layanan online tersebut ketika membutuhkan pelayanan dari pemerintah, dan ikut serta memberi masukan kepada pemerintah terkait peningkatan-peningkatan yang dibutuhkan. Hal tersebut sejalan dengan hasil penelitian yang dilakukan oleh Schellong (2008), bahwa partisipasi masyarakat terdiri atas dua sisi, yaitu yang pertama adalah self service, fungsi pelayanan dilakukan oleh masyarakat sendiri melalui aplikasi online, dan yang kedua adalah pemberian umpan balik/kritik dari masyarakat terkait layanan online yang disediakan, kebijakan, dan lain-lain.

\subsection{Fungsionalitas layanan}

Sebuah pelayanan yang beralih dari tradisional/offline ke layanan online tentunya tetap harus dapat membantu masyarakat memenuhi kebutuhannya. Tabel 5 menunjukkan pernyataan dari wawancara terhadap informan yang diperoleh hasil bahwa, perlu tersedianya informasi yang berisi tentang layanan online dan petunjuk penggunaan dari layanan tersebut. Selain informasi dan panduan 
pengguna, layanan online yang disediakan juga harus dapat menyediakan fungsi-fungsi yang berkaitan dengan proses layanan yang dibutuhkan masyarakat, seperti upload, download, pengisian form, cetak, dan histori. Bahkan masyarakat menginginkan adanya pengiriman dokumen ke rumah dari yang sebelumnya harus diambil ke kantor. Fitur lain yang diinginkan oleh masyarakat adalah apabila ketika mengakses layanan, masyarakat perlu melakukan proses pembayaran, mereka dapat melakukan pembayaran secara online. Selain itu, ada notifikasi kesalahan ketika pengguna mengisi form yang terdapat di dalam aplikasi online atau melakukan sesuatu yang di luar prosedur serta solusi perbaikan. Secara umum, hal tersebut sesuai dengan pernyataan (Fath-Allah, Cheikhi, Al-Qutaish, \& Idri, 2014), yaitu sebuah layanan e-government biasanya memiliki empat fungsionalitas utama, yaitu ketersediaan informasi pada situs jejaring (presence), kemampuan yang memungkinkan masyarakat dapat berinteraksi (interact), bertransaksi (transact) dengan pemerintah, dan integrasi berbagai layanan.

Tabel 5. Transkrip wawancara 5

\begin{tabular}{cl}
\hline Informan & \multicolumn{1}{c}{ Pernyataan } \\
\hline Informan 8 & $\begin{array}{l}\text { Jadi ada petunjuknya untuk sebelum ngisi itu ada syarat yang harus dikumpulin dulu, } \\
\text { kelengkapannya apa aja dikumpulin dulu baru nanti diisi di formulirnya. }\end{array}$ \\
Informan 12 & $\begin{array}{l}\text { Untuk sistemnya saya rasa sudah cukup karena input-input datanya juga sudah ada semacam } \\
\text { bantuan, semacam pop-up mana yang harus diisi. }\end{array}$ \\
Informan 16 & $\begin{array}{l}\text { Selain informasi dan layanan itu juga ada interaksi dengan petugas, bisa chat, video conference } \\
\text { atau apa yang seperti itu, yang sekiranya memang diperlukan oleh warga. }\end{array}$ \\
Informan 18 & $\begin{array}{l}\text { Selain informasi dan layanan itu, juga ada interaksi dengan petugas, bisa chat, video conference } \\
\text { yang sekiranya memang diperlukan oleh warga. Untuk yang transaksi baik itu yang layanan } \\
\text { maupun uang perlu ada metode-metode pembayaran, metode-metode pengambilan serah } \\
\text { terima berkas (upload, download, berkas diterima di rumah). }\end{array}$ \\
Informan 19 19 & $\begin{array}{l}\text { Kalo bisa ada payment, itu kaya pengurusan PBB itu tetep harus ke bank jatim baru dapet bukti } \\
\text { pembayaran. Kalo bisa via online sih enak, klo ada online payment. }\end{array}$ \\
Jnforman 20 & $\begin{array}{l}\text { Jadi pada waktu ditolak itu kita sudah ada solusinya. Jadi cara meng-input juga ndak error, ndak } \\
\text { lemot, terus respon setelah kita upload semuanya, 2 atau } 3 \text { jam baru ada feedback atau report } \\
\text { sebagai pemberitahuan bahwa hasil dari pendaftaran itu sudah di acc atau tidak itu sudah ada } \\
\text { melalui sms dan email. }\end{array}$ \\
Kalo bisa sih itu ada untuk mengumpulkan feedback.
\end{tabular}

\subsection{Integrasi layanan}

Pelayanan yang diberikan oleh pemerintah sangat banyak jenisnya. Meski berbagai pelayanan tersebut diselenggarakan oleh dinas yang berbeda, tetapi ada beberapa pelayanan yang terkait satu sama lain. Ada dua tindakan yang dapat dilakukan oleh pemerintah untuk mengelola informasi terkait masyarakat. Pendekatan yang pertama adalah melakukan sentralisasi sistem/layanan. Lembaga/departemen pemerintah tidak bergantung pada koordinasi antardepartmen, tetapi pada satu pusat informasi. Lembaga/departemen pemerintah tersebut mengumpulkan dan mengevaluasi data mentah, lalu mengolahnya untuk pusat informasi. Informasi yang disimpan pada pusat informasi dapat diakses dan digunakan oleh berbagai departemen lainnya untuk proses pengolahan lebih lanjut. Pendekatan yang kedua adalah melakukan desentralisasi sistem/layanan. Informasi terkait masyarakat tidak perlu melalui perantara, misalnya pusat informasi sebelum mencapai tujuannya. Tiap departemen/lembaga pemerintah dapat mengembangkan sistem informasi milik mereka yang dapat diakses oleh lembaga/departemen lain. Struktur seperti ini meningkatkan kerja sama dan koordinasi antardepartemen dan sebagai hasilnya departemen/lembaga pemerintah dapat mengolah permintaan masyarakat dengan lebih cepat (Andrade \& Camacho, 2014).

Tabel 6. Transkrip wawancara 6

\begin{tabular}{cl}
\hline Informan & \multicolumn{1}{c}{ Pernyataan } \\
\hline Informan 7 & Jadi setiap layanan pemkot itu kalo bisa saling terintegrasi sama layanan yang lain. Kalo bisa \\
& juga layanan pemerintah pusat juga kaya KPP, data-datanya kan itu terintegrasi semua. Jadi kita \\
& $\begin{array}{l}\text { ga perlu ngumpulkan fotokopi KTP, SKPT, tinggal masukkan, nanti terhubung, data-datanya } \\
\text { diambilkan sana semua kalo bisa. }\end{array}$ \\
Informan 9 & $\begin{array}{l}\text { Kadang SSW itu bener aplikasinya terintegrasi, tapi layanannya di lapangan tetep masih ada } \\
\text { yang harus ke kantor satu, ke kantor yang lain. Nah ini harapannya ke depan, semua layanan } \\
\text { itu bisa diintegrasikan dengan e-lampid atau aplikasi lainnya. }\end{array}$ \\
\hline
\end{tabular}


Hasil penelitian, seperti yang ditunjukkan pada Tabel 6, menunjukkan pernyataan dari wawancara terhadap informan, bahwa masyarakat pun memiliki pandangan yang sejalan dengan pernyataan pada Tabel 6. Masyarakat menginginkan adanya integrasi sistem layanan online, baik yang berkaitan dengan pelayanan kepada publik maupun yang berkaitan dengan internal pemerintah. Tujuannya adalah agar mereka dapat memperoleh apa yang dibutuhkan dengan hanya mengakses satu layanan, sehingga proses pelayanan pun menjadi lebih mudah dan cepat. Apa pun bentuk integrasi layanan yang hendak dilakukan, baik sentralisasi maupun desentralisasi, harus mampu menjawab kebutuhan masyarakat.

\subsection{Kemudahan penggunaan}

Tabel 7. Transkrip wawancara 7

\begin{tabular}{ll}
\hline \multicolumn{1}{c}{ Informan } & \multicolumn{1}{c}{ Pernyataan } \\
\hline Informan 5 & Aplikatif dan User friendly. \\
Informan 11 & $\begin{array}{l}\text { Sistemnya, karena saya rasa sistemnya sudah sempurna karena sudah benar-benar sesuai } \\
\text { dengan kebutuhan UPTSA sendiri dan kita juga mudah untuk mengaplikasikan. Jadi cara meng- } \\
\text { input juga ndak error, ndak lemot. }\end{array}$ \\
Informan 16 & Yang pasti itu tadi kemudahan, kalo bisa menggantikan dokumen kertas. \\
Informan 18 & $\begin{array}{l}\text { Yang saya harapkan pastinya yang mudah diakses ya mbak, terutama ketika diakses itu tidak } \\
\text { lambat. Biasanya kalo terlalu banyak konten itu kan selain lambat juga makan data. Terus yang } \\
\end{array}$ \\
\hline
\end{tabular}

Meski sebelumnya, kemudahan penggunaan layanan tidak menjadi faktor yang dipertimbangkan dalam menilai keberhasilan layanan e-government, ternyata penelitian menunjukkan hasil yang berbeda. Masyarakat menginginkan pelayanan publik yang dapat diakses tanpa harus mendatangi kantor pemerintahan. Ketika ditanya tentang aplikasi seperti apa yang diinginkan, Tabel 7 menunjukkan pernyataan dari wawancara terhadap informan.

Jawaban tersebut menunjukkan bahwa, selain memiliki kelengkapan fungsi, layanan online yang disediakan haruslah mudah digunakan, memiliki berbagai fungsi yang sesuai dengan kebutuhan masyarakat, dan tersedia sepanjang waktu. Hal ini sejalan dengan penelitian (Papadomichelaki \& Mentzas, 2012) yang menilai kualitas e-government dari sisi kemudahan penggunaan, fungsionalitas, reliabilitas, dan tampilan informasi.

\subsection{Kehandalan (reliability) layanan}

Reliabilitas didefinisikan sebagai tingkat kepercayaan masyarakat terhadap layanan e-government terkait pengiriman data yang benar dan cepat. Reliabilitas mencakup berjalannya fungsi-fungsi teknis (accessibility dan availability) dan akurasi layanan sesuai dengan yang dijanjikan. Accessibility adalah sejauh mana suatu sistem dapat digunakan oleh sebanyak mungkin orang tanpa perlu dilakukan modifikasi layanan. Availability mengacu pada sejauh mana penurunan atau interupsi layanan yang dialami suatu sistem ketika terjadi kegagalan pada satu atau beberapa bagian-bagiannya.

Tabel 8. Transkrip wawancara 8

\begin{tabular}{cl}
\hline Informan & Pernyataan \\
\hline Informan 2 & Yang penggunaannya simple. Fungi-fungsi yang ada yang dibutuhkan aja, user interface-nya \\
& enak, ngisinya enak, cepet terus diaksesnya ga lemot.
\end{tabular}

Informan 18 Yang saya harapkan pastinya yang mudah diakses ya mbak, terutama ketika diakses itu tidak lambat. Biasanya kalo terlalu banyak konten itu kan selain lambat juga makan data. Terus yang kedua itu yang simple ya, user friendly. Yang cepet dan tidak ribet. Kaya misalkan antara warga kelas menengah ke atas sama kelas menengah ke bawah, mungkin kalo kelas menengah ke atas bisa ada versi mobile, versi Google Playstore. Kemudian kalo kelas menengah ke bawah mungkin bisa kaya semacam agen-agen toko pulsa.

Informan 20 Sistem online sekarang ini bukan hanya ada di internet, tapi juga di mobil keliling dan Android. Jadi mobil keliling insyaa Allah secepatnya akan di-launching di Taman Bungkul.

Sesuai hasil wawancara pada Tabel 8, masyarakat menginginkan proses yang cepat saat mengunduh atau mengunggah dokumen/form pada layanan online, kemudahan akses terhadap layanan online, layanan online mampu menyelesaikan proses pelayanan tanpa harus dilakukan berulang-ulang, proses pelayanan pada layanan online yang cepat serta kompatibilitas layanan online terhadap 

(Papadomichelaki \& Mentzas, 2012).

\section{Kesimpulan}

Berdasarkan hasil penelitian yang dilakukan, dapat disimpulkan bahwa ada tiga dimensi yang diukur dalam penilaian kematangan e-government berorientasi kepada masyarakat, yaitu lembaga, interaksi dan layanan online. Dimensi lembaga terdiri atas dua variabel, yaitu budaya dan kebijakan yang berorientasi kepada masyarakat. Empat variabel dievaluasi dalam dimensi layanan, yaitu kemudahan penggunaan, fungsionalitas, keandalan, dan integrasi sistem. Sementara itu, dimensi interaksi terdiri atas dua variabel, yaitu partisipasi pegawai pemerintah dan masyarakat.

Kami mengakui bahwa, penelitian ini tidak lebih dari langkah pertama menuju alat penilaian kematangan e-government yang secara teoretis dan praktis berorientasi pada e-government. Untuk mencapai tujuan akhir, dalam melakukan penelitian ini harus diatasi beberapa batasan kritis, yang harus ditangani dalam penelitian selanjutnya. Pertama, penelitian ini hanya menggunakan dua aplikasi online sebagai objek penelitiannya. Penelitian masa depan perlu menambahkan beberapa objek lain untuk mendapatkan perspektif yang lebih komprehensif. Kedua, informan yang dipilih adalah mereka yang memiliki latar belakang dan pengalaman dalam mengembangkan layanan online. Selain itu, informan hanya dipilih dari masyarakat, sehingga faktor-faktor yang digunakan untuk menilai kematangan e-government diperoleh dari satu sudut pandang saja. Penelitian masa depan harus menambahkan informan dari segmen yang berbeda, misalnya pegawai pemerintah dan bisnis, sehingga mendapatkan faktor pengukuran kematangan yang lebih komprehensif. Ketiga, belum dirumuskannya metode penilaian kematangan implementasi e-government. Ada beberapa faktor yang penilaiannya harus didasarkan pada bukti terdokumentasi dari implementasi e-government yang berorientasi kepada masyarakat, misalnya kebijakan. Studi selanjutnya diharapkan mampu menentukan metode penilaian yang cocok dengan seluruh faktor kematangan sekaligus penetapan level kematangannya.

\section{Ucapan Terima Kasih}

Penelitian ini didukung oleh APBN melalui Dirjen Pendidikan Tinggi di bawah program Penelitian Dosen Pemula Tahun 2018.

\section{Referensi}

Alshibly, H., \& Chiong, R. (2015). Customer empowerment: Does it influence electronic government success? A citizen-centric perspective. Electronic Commerce Research and Applications, 14(6), 393-404.

Andrade, V., \& Camacho, P. (2014). Citizen relationship management: What are the determinants that influence the implementation of citizen relationship management in governments? 2014 First International Conference on eDemocracy \& eGovernment (ICEDEG) (pp. 97-102). Quito, Ecuador: IEEE.

Creswell, J. W. (2015). Qualitative Inquiry and Research Design: Choosing Among Five Approaches (3rd ed. ed.). Yogyakarta: Sage publications.

Debrí, F., \& Bannister, F. (2015). E-government Stage Models: A Contextual Critique. 2015 48th Hawaii International Conference on System Sciences (pp. 2222-2231). Kauai, HI, USA: IEEE.

Eijk, C. J., \& Steen, T. P. (2014). Why People Co-Produce: Analysing citizens' perceptions on co-planning engagement in health care services. Public Management Review, 16(3), 358-382.

Fath-Allah, A., Cheikhi, L., Al-Qutaish, R. E., \& Idri, A. (2014). E-government maturity models: A comparative study. International Journal of Software Engineering \& Applications (IJSEA), 5(3), 71-91.

Garrido-Moreno, A., Lockett, N., \& García-Morales, V. (2014). Paving the way for CRM success: The mediating role of knowledge management and organizational commitment. Information $\mathcal{E}$ Management, 51(8), 1031-1042.

Giesbrecht, T., Scholl, H. J., \& Schwabe, G. (2016). Smart advisors in the front office: Designing employee-empowering and citizen-centric services. Government Information Quarterly, 33(4), 669-684.

Greitens, T. J., \& Strachan, J. C. (2011). E-government and Citizen Engagement: An Overview of US States' Government Websites. International Journal of Public Administration, 34(1-2), 54-58. 
Lawson-Body, A., Willoughby, L., Mukankusi, L., \& Logossah, K. (2011). The Critical Success Factors for Public Sector CRM Implementation. Journal of Computer Information Systems, 52(2), 42-50.

Napitupulu, D., \& Sensuse, D. I. (2014). Toward maturity model of e-Government implementation based on success factors. 2014 International Conference on Advanced Computer Science and Information System (pp. 104-112). Jakarta, Indonesia: IEEE.

Nations, U. (2003). World Public Sector Report 2003: E-Government at the Crossroads. New York: United Nations.

Osman, I. H., Anouze, A. L., Irani, Z., Al-Ayoubi, B., HabinLee, Balc1, A., . . Weerakkody, V. (2014). COBRA framework to evaluate e-government services: A citizen-centric perspective. Government Information Quarterly, 31(2), 243-256.

Papadomichelaki, X., \& Mentzas, G. (2012). e-GovQual: A multiple-item scale for assessing egovernment service quality. Government Information Quarterly, 29(1), 98-109.

Robertson, S. P., \& Vatrapu, R. K. (2010). Digital government. Annual Review of Information Science and Technology, 44(1), 317-364.

Schellong, A. (2008). Citizen relationship management. In Electronic Government: Concepts, Methodologies, Tools, and Applications (pp. 2567-2579). London: IGI Global.

Shahkooh, K. A., Saghafi, F., \& Abdollahi, A. (2008). A Proposed Model for E-government Maturity. 2008 3rd International Conference on Information and Communication Technologies: From Theory to Applications (pp. 1-5). Damascus, Syria: IEEE.

Tavana, M., Zandi, F., \& Katehakis, M. N. (2013). A hybrid fuzzy group ANP-TOPSIS framework for assessment of e-government readiness from a CiRM perspective. Information $\mathcal{E}$ Management, 50(7), 383-397. 